Introdução a uma Clínica Diferencial das Psicoeses

Contardo Calligaris

São Paulo: Zagodoni, 2013, 138 págs.

\title{
Relançar de uma experiência: a clínica psicanalítica e as psicoses
}

\author{
Lucia Serrano Pereira*
}

Introdução a uma Clínica Diferencial das Psicoses tem sua reedição lançada, vinte e poucos anos depois do seu primeiro tempo. Momento que condensa toda uma discussão clínica sobre as psicoses, ao final dos anos 1980, intensa, e de importância fundamental, para os psicanalistas e para a psicanálise de um modo geral.

$\mathrm{O}$ texto tem a peculiaridade de seguir o tom da fala que Contardo Calligaris, o autor, introduziu nos encontros do Seminário sobre Psicoses, em Porto Alegre, mantendo a trama aberta da discussão in loco.

$\mathrm{Na}$ apresentação a esta segunda edição, Contardo confidencia ao leitor que, antes de qualquer coisa, o livro diz de sua maneira própria de clinicar com psicóticos. Ponto fundamental que, naquele momento, não era óbvio para nós. Mas o fato é que saíamos muito implicados daqueles encontros, e a complexidade de algumas das questões, ontem lançadas, permanecem ainda hoje. Como por exemplo: $\mathrm{O}$ que pode ser uma análise quando se trata de um paciente psicótico? Que tipo de transferência pode estabelecer um psicótico com um psicanalista?

* Associação Psicanalítica de Porto Alegre - APPOA (Porto Alegre, RS, Br). 
E mais ainda, o desafio de como pensar as relações da psicose com o nosso mundo - onde boa parte dos delírios tem conteúdo cultural e são precipitados por injunções produzidas na cultura incidindo sobre o sujeito.

No encontro para o relançamento do livro, Calligaris nos falou da importância, para sua trajetória clínica, da atividade da apresentação de pacientes de Lacan. Ressalta que nessa prática o que mais importava era a reconstituição das condições em que a crise do paciente tinha se desencadeado; além da proposta de situar por que aquilo que se escutava na entrevista seria indício de uma psicose.

A clínica diferencial pode dizer respeito às diferentes maneiras de ser tomado em uma psicose, seja a paranoia, a psicose maníaco-depressiva ou uma esquizofrenia (com suas constelações simbólicas e imaginárias específicas passando pelas relações com a obsessão, a fobia e a histeria). Mas o diferencial que se marca aqui, é poder abordar de frente o que situa discursivamente uma psicose. Por onde ela se sustenta e qual a sua especificidade. Como dizer algo, a partir daí, que não seja somente uma definição pelo negativo, na relação com outras configurações da psicopatologia. E é claro que isso vai contar de maneira forte nos efeitos e consequências na direção do tratamento.

Interrogar o momento que se segue a uma crise, afirma Contardo, é oferecer ao sujeito uma possibilidade, uma chance. Nesse sentido, poder falar do caminho que foi trilhado até a crise pode ser crucial, para o sujeito, assim como o tempo de compartilhar a significação, a metáfora delirante que o está sustentando.

A errância psicótica; as relações entre o saber, o delírio e as totalizações; as injunções (que precipitam retornos no Real, pelo fato do sujeito não encontrar recursos no Simbólico e no Imaginário para responder), o crepúsculo - quando o saber que dava uma sustentaçāo ao "eu" entra em colapso; a escuta de pacientes em crise e daqueles que nunca encontraram uma crise; as passagens estabelecem a especificidade da clínica que vai se desdobrando ao longo do livro.

O que descreve são errâncias infinitas, operações de defesa totalizantes, como, por exemplo, produzir uma rede de proteção total: "como a tarefa de uma aranha que teria que encasular preventivamente um perigoso inimigo do tamanho do mundo". Podem ser também errâncias intelectuais. Pensamentos coerentes e organizados, mas sempre com um horizonte de totalidade, como que autoengendrados, que não autorizam uma transmissão, ou reconhecem uma dívida. Ao mesmo tempo, o que é sublinhado é que o aporte da psicose à cultura é enorme, ideias que são cruciais para todos nós, como por exemplo Emílio, de Rousseau, ou a obra de Wittgenstein, que também era um paranoico. Ou seja, é importante lembrar que a experiência da psicose tem enriquecido a humanidade.

O que perpassa a clínica diferencial das psicoses é a posição que sempre acompanhou a transmissão de Contardo: a fala de um sujeito vai desdobrar, em exercício, sua estrutura, e assim o que conta, seja para diagnóstico, seja para realizar 


\section{RESENHA DE LIVROS}

a experiência do inconsciente em uma análise, é o lugar onde o analista está colocado, na transferência, a partir da fala do paciente.

Essa forma de clinicar aportou uma leitura de tanta ousadia, rigor e clareza que é difícil dizer hoje de todos os efeitos que produziu. O mais forte, sem dúvida, foi o de encorajar toda uma geração (ou mais) a tomar a responsabilidade e o desejo de sustentar uma clínica com as psicoses nos tempos atuais.

\section{Lucia Serrano Pereira}

Psicanalista; Membro da Associação Psicanalítica de Porto Alegre - APPOA (Porto Alegre, RS, Br); Pós-doutora em Psicologia Social e Institucional pela Universidade Federal do Rio Grande do Sul -UFRGS (Porto Alegre, RS, Br); Doutora em Literatura Brasileira pela mesma universidade; Autora dos livros Que queres tu de mim? (Ed. Unisinos, 2011); O conto machadiano, uma experiência de vertigem (Cia. de Freud, 2008); Audio livro A cartomante e a vertigem (Ed. Ideias a Granel, 2010); Um narrador incerto entre o estranho e o familiar (Cia. de Freud, 2004), entre outras publicações de artigos.

Av. Eng. Alfredo Correa Daudt, 445 - Boa Vista 90480-120 Porto Alegre, RS, Br e-mail: luciaserranopereira@gmail.com 